\title{
ANALISIS PENGARUH KUALITAS LAYANAN AKADEMIK TERHADAP KEPUASAN DAN LOYALITAS MAHASISWA
}

\section{(Studi kasus pada mahasiswa Universitas Halmahera Program Studi Manajemen dan Ilmu}

Pemerintahan Angkatan Tahun 2008-2016)

\author{
Yonas Meti \\ Deiby Ch. Tinggogoy \\ FakultasIlmuSosial-Universitas Halmahera-Tobelo \\ christianadeiby@gmail.com
}

\begin{abstract}
ABSTRAK
Penelitian ini dilakukan untuk menguji pengaruh variabel Kualitas Pelayanan dan Fasilitas Kampus terhadap Kepuasan dan Loyalitas Mahasiswa pada mahasiswa Manajemen dan Ilmu Pemerintahan Universitas Halmahera.

Populasi dalam penelitian ini adalah seluruh mahasiswa manajemen Universitas Halmahera angkatan tahun 2008-2016. Pengambilan sampel dilakukan dengan menggunakan metode purposive sampling sehingga dalam penelitian ini jumlah sampel sebanyak 50 orang mahasiswa Manajemen dan Ilmu Pemerintahan Universitas Halmahera angkatan tahun 20082016.
\end{abstract}

Pengujian asumsi klasik meliputi uji normalitas, uji multikolinearitas, uji autokorelasi, dan uji heteroskedastisitas. Analisis data digunakan dengan menggunakan analisis jalur dengan bantuan program SPSS.

Kata kunci: Kualitas Pelayanan, Fasiltas, Kepuasan dan Loyalitas.

\section{PENDAHULUAN}

\section{Latar Belakang}

Kualitas pelayanan merupakan suatu driver kepuasan yang bersifat multidimensi. Tingkat kualitas pelayanan tidak dapat dinilai berdasarkan sudut pandang perusahaan tetapi harus dipandang dari sudut pandang penilaian pelanggan. Kepuasan dari sisi konsumen dipandang baik apabila memenuhi apa yang mereka harapkan, sebaliknya pelayanan akan dipersepsikan buruk apabila tidak memenuhi yang mereka harapkan (Kotler, 2000: 45). Kepuasan pelanggan sebagai persepsi terhadap produk atau jasa yang telah memenuhi harapannya. Teori consumer behavior menyatakan bahwa kepuasan pelanggan adalah persepektif pengalaman konsumen setelah mengkonsumsi atau menggunakan produk atau 
jasa. (Oliver,1993: 65). Kepuasan pelanggan diharapkan akan berpengaruh terhadap loyalitas. Pelanggan yang loyal dapat memberikan keuntungan yang besar terhadap organisasi.

Menurut pendapat parasuraman (2006), bahwa pelayanan dikatakan memuaskan jika layanan yang dirasakan sama atau melebihi kualitas layanan yang diharapkan. Pelayanan yang seperti ini dipersepsikan sebagai pelayanan yang berkualitas dan ideal. Harapan pelanggan tersebut tercermin padadimensi kualitas pelayanan seperti yang ditemukan Parasuraman dalam Purnama (2006) yang menyebutkan bahwa ada lima dimensi kualitas pelayanan yaitu tangible (bukti fisik), realiability (keandalan), responsiveness (daya tanggap), assurance (jaminan) dan empathy (empati). Dalam penelitian Zeithaml dalam Husaini Usman (2006 :494) mengenai kualitas pelayanan menyimpulkan bahwa perguruan tinggi berdasarkan lima dimensi kualitas pelayanan tersebut di atas semuanya dalam kategori buruk.

Kegiatan akademik menjadi isu yang perlu mendapat perhatian dari seluruh komponen yang terkait dalam pengembangan Universitas Halmahera. Pelayanan akademik sangat bersentuhan dengan dimensi-dimensi kualitas pelayanan, agar mahasiswa yang dilayani merasa puas dan akhirnya mepunyai loyalitas terhadap instansi atau lembaganya. Loyalitas mahasiswa yang tinggi tidak dapat langsung diperoleh dengan memberikan kualitas pelayanan akademik yang baik saja, namun harus dievaluasi juga kepuasan mahasiswa mereka. Kepuasan yang tinggi tentunya akan berdampak kepada loyalitas yang tinggi pula. Berikut adalah data mahasiswa Prodi Manajemen dan Prodi Ilmu Pemerintahan yang aktif selama periode angkatan tahun 2008 sampai dengan 2016 pada setiap semester:

\begin{tabular}{|c|c|c|c|c|c|}
\hline \multirow{2}{*}{ NO } & \multirow{2}{*}{ TAHUN } & \multicolumn{2}{|c|}{ PRODI } & \multicolumn{2}{c|}{ PRODI IP } \\
\cline { 3 - 6 } & & GENAP & GANJIL & GENAP & GANJIL \\
\hline 1 & 2008 & 52 & 40 & 0 & 0 \\
2 & 2009 & 46 & 35 & 63 & 54 \\
3 & 2010 & 56 & 30 & 190 & 115 \\
4 & 2011 & 57 & 50 & 202 & 192 \\
5 & 2012 & 61 & 55 & 186 & 165 \\
6 & 2013 & 62 & 55 & 194 & 173 \\
7 & 2014 & 52 & 51 & 149 & 148 \\
8 & 2015 & 62 & 65 & 142 & 134 \\
9 & 2016 & 81 & 69 & 133 & 119 \\
\hline
\end{tabular}

Berdasarkan uraian diatas, maka sangat penting untuk mengetahui kualitas pelayanan berpengaruh terhadap kepuasan dan dampaknya pada kepercayaan mahasiswa di Universitas Halmahera Program Studi Manajemen dan, maka akan memberikan kepuasan dan kenyamanan 
bagi mahasiswa oleh karena itulah penulis melakukan penelitian dengan judul "AnalisisPengaruh Kualitas Pelayanan Akademik Dan Fasilitas Kampus Terhadap Kepuasan dan Loyalitas Mahasiswa"

\section{Rumusan Masalah}

Berdasarkan latar belakang yang telah di uraikan diatas, maka yang menjadi rumusan masalah dalam penelitian ini adalah :

1. bagaimana kualitas pelayanan akademik berpengaruh terhadap kepuasan mahasiswa?

2. Bagaimana pelayanan akademik berpengaruh terhadap loyalitas mahasiswa?

3. Bagaimana kualitas pelayanan dan kepuasan berpengaruh loyalitas mahasiswa?

\section{Tujuan Penelitian}

Tujuan Penelitian ini adalah :

1. Untuk mengetahuipengaruh kualitas pelayanan akademik terhadap kepuasan mahasiswa.

2. Untuk mengetahui pengaruh kualitas pelayanan akademik terhadap loyalitas mahasiswa.

3. Untuk mengetahui pengaruh kualitas pelayanan dan kepuasan terhadap loyalitas mahasiswa.

\section{Manfaat Penelitian}

Manfaat dari penelitian ini adalah:

1. Hasil penelitian ini diharapkan menjadi bahan acuan bagi Universitas Halmahera di dalam pengambilan keputusan dan menentukan kebijakan-kebijakan dalam rangka meningkatkan kepuasan dan loyalitas mahasiswa.

2. Penelitian ini diharapkan dapat memberikan informasi untuk mengetahui pengaruh kualitas pelayanan dan fasilitas kampus dengan kepuasan dan loyalitas mahasiswa.

\section{LANDASAN TEORI}

\section{Kualitas Layanan}

Kualitas merupakan perpaduan antara sifat dan karakteristik yang menentukan sejauh mana keluaran dapat memenuhi persyaratan kebutuhan pelanggan. Pelanggan yang menentukan dan menilai sampai seberapa jauh sifat dan karakteristik tersebut memenuhi kebutuhannya (Lupiyoadi, 2014). Kualitas adalah sebuah kata yang bagi penyedia jasa merupakan sesuatu yang harus dikerjakan dengan baik (Supranto, 2011). Menurut Tjiptono (2008) secara sederhana istilah service mungkin bisa diartikan sebagai melakukan sesuatu bagi orang lain.

Sementaraitu, definisi pelayanan menurut Gronroos adalah suatu aktivitas atau serangkaian aktivitas yang bersifat tidak kasat mata yang terjadi sebagai akibat adanya interaksi antara konsumen dengan karyawan atau hal-hal lain yang disediakan oleh perusahaan pemberi pelayanan yang dimaksud untuk memecahkan permasalahan 
konsumen/pelanggan (Ratminto, 2010).Kepuasan pelanggan dalam praktek tidak cukup hanya dengan terpenuhinya kepuasan pribadi untuk melayani konsumen yang bersangkutan tetapi juga harus diperhatikan hal-hal sebagai berikut:

1. Pelanggan adalah orang paling penting.

2. Pelanggan adalah objek yang dapat memberikan keuntungan bagi perusahaan.

3. Pelanggan bukanlah lawan bicara yang perlu diajak berdebat, bila terpaksa, maka pihak yang menang haruslah pihak pelanggan.

4. Pelanggan adalah raja, sekali ia kalah dalam beragumentasi maka ia akan pindah ke produk lain.

5. Pelanggan adalah manusia biasa yang memiliki perasaan senang, benci, bosan, dan adakalanya mempunyai prasangka yang tidak beralasan.

6. Pelanggan dalam usaha mendapatkan pelayanan selalu ingin didahulukan, diperhatikan, dan ingin diistimewakan serta tidak ingin diremehkan begitu saja.

\section{Kepuasan Pelanggan}

Kepuasan adalah tingkat perasaan seseorang setelah membandingkan kinerja/ hasil yang dirasakannya dengan harapannya (Oliver, 1980) dikutip oleh Supranto (2011). Jadi, tingkat kepuasan merupakan fungsi dari perbedaan antara kinerja yang dirasakan dengan harapan. Apabila kinerja di bawah harapan, maka pelanggan akan kecewa. Bila kinerja sesuai dengan harapan, pelanggan akan puas. Sedangkan bila kinerja melebihi harapan, pelanggan akan sangat puas.

Menurut Philip Kotler dan Kevin Lane Keller yang dikutip dari buku Manajemen Pemasaran mengatakan bahwa kepuasan konsumen adalah perasaan senang atau kecewa seseorang yang muncul setelah membandingkan kinerja atau hasil produk yang dipikirkan terhadap kinerja yang diharapkan (2007:177)

\section{Hipotesis Penelitian}

Berdasarkan rumusan masalah dan kerangka pemikiran, maka hipotesis dalam penelitian ini adalah:

1. Kualitas layanan berpengaruh positif terhadap kepuasan mahasiswa

2. Kualitas layanan berpengaruh positif pada loyalitas mahasiswa

3. Kualitas layanan dan Kepuasan Mahasiswa berpengaruh positif pada kepuasan mahasiswa

\section{METODE PENELITIAN}

\section{Jenis dan Sumber Data}

Penelitian ini merupakan penelitian asosiatif. Penelitian asosiatif merupakan penelitian yang bertujuan untuk mengetahui hubungan antara dua variabel atau lebih (Sugiyono, 2006). Hubungan antara variabel dalam penelitian ini adalah hubungan kausal. 


\section{Populasi dan Sampel}

\section{Populasi}

Populasi adalah gabungan dari seluruh elemen yang berbentuk peristiwa, hal atau orang yang memiliki karakteristik yang serupa yang menjadi pusat perhatian seorang peneliti karena dipandang sebagai semesta penelitian. Elemen populasi adalah setiap anggota dari populasi yang diamati (Ferdinand, 2006 ). Dari penjelasan di atas mengenai populasi, maka populasi dalam penelitian ini adalah semua mahasiswa Prodi Manajemen dan Prodi Ilmu Pemerintahan angkatan tahun 2008-2016.

\section{Sampel}

Sampel adalah subset dari populasi, terdiri dari beberapa anggota populasi. Subset ini diambil karena dalam banyak kasus tidak mungkin kita meneliti seluruh anggota populasi, oleh karena itu kita membentuk suatu perwakilan populasi yang disebut sampel (Ferdinand, 2006). Sampel pada penelitian ini ditentukan dengan menggunakan teknik non probability, yaitu teknik pengambilan sampel yang tidak memberi peluang atau kesempatan sama bagi setiap unsur atau anggota populasi untuk dipilih menjadi sampel. Dimana penelitian ini menggunakan sampling insidental adalah cara pengambilan sampel secara kebetulan yang bertemu dengan peneliti.

\section{Jenis Data dan Sumber Data}

Data memegang peranan penting yaitu sebagai alat pembuktian hipotesis serta pencapaian tujuan penelitian. Data yang digunakan dalam penelitian ini adalah data primer. Data primer adalah data yang berasal langsung dari responden. Data primer dalam penelitian ini diperoleh dari kuesioner yang diisi oleh responden, meliputi: identitas dan tanggapanresponden mengenai kualitas pelayanan, Fasilitas Kampus, kepuasan mahasiswa dan loyalitas mahasiswa.

\section{Metode Pengumpulan Data}

Metode pengumpulan data adalah kuesioner, yaitu metode pengumpulan data yang dilakukan dengan mengajukan lembaran angket yang berisi daftar pertanyaan kepada responden. Pengukuran variabel penelitian ini dilakukan dengan menggunakan kuesioner secara personal (Personality Quesitionnaires). Data dikumpulkan dengan menggunakan angket tertutup.

\section{Metode Analisis Data}

Dalam penelitian ini analisis data dilakukan dengan analisis jalur (path analysis). Model path digunakan untuk menganalisis pola hubungan antar variable dengan tujuan untuk mengetahui pengaruh langsung variabel bebas terhadap variable terikat. Analisis jalur dilakukan setelah model yang digunakan terbebas asumsi klasik. Tujuannya adalah agar hasil penelitian ini dapat diinterpretasikan secara tepat dan efisien. Interpretasi hasil penelitian baik 
secara parsial maupun secara simultan hanya dilakukan terhadap variabel-variabel independen yang secara statistik mempunyai pengaruh terhadap variable dependen.

\section{ANALISIS DATA DAN PEMBAHASAN}

\section{Karakterisktik Responden}

Pada bagian ini akan dibahas mengenai gambaran karakteristik responden yang berdasarkan jenis kelamin, program studi,dan angkatan dalam kepuasan mahasiswa. Pengumpulan data responden ini dilakukan menggunakan teknik insidental sampling yaitu teknik penentuan sampel berdasarkan kebetulan, yang berarti siapa saja yang secara kebetulan/insidental bertemu dengan peneliti dapat digunakan sebagai sampel, bila dipandang orang yang kebetulan ditemui itu cocok sebagai sumber data. Penelitian ini dilakukan pada mahasiswa/i di Fakultas Ilmu Sosial Dan HumanioraUniversitas Halmahera dengan jumlah responden sebanyak 100 orang.

\section{Tabel 4.1}

Distribusi Karakteristik Responden

\begin{tabular}{|c|c|c|c|c|}
\hline No & $\begin{array}{c}\text { Angkatan } \\
\text { Tahun }\end{array}$ & Jumlah & Laki Laki & Perempuan \\
\hline 1 & 2011 & - & - & - \\
\hline 2 & 2012 & 3 & 3 & 1 \\
\hline 3 & 2013 & 5 & 4 & 4 \\
\hline 4 & 2014 & 10 & 6 & 8 \\
\hline 5 & 2015 & 22 & 14 & 22 \\
\hline 6 & 2016 & 30 & 8 & 10 \\
\hline 7 & 2017 & 30 & 20 & \\
\hline Jumlah Responden & 100 Orang & &
\end{tabular}

Berdasarkan keterangan pada tabel 4.1 di atas, dapat diketahui tentang jenis kelamin responden Mahasiswa Fakultas Ilmu Sosial Dan Humaniora diambil sebagai responden, yang menunjukkan bahwa mayoritas responden adalah laki-laki, yaitu sebanyak 55 orang dengan presentase 55,\%, sedangkan sisanya adalah responden Perempuan sebanyak 45 orang dengan presentase $45 \%$. Selanjutnya berdasarkan keterangan dari tabel 4.1 di atas dapat diketahui bahwa responden dalam penelitian ini dilakukan dengan memberikan kuesioner kepada mahasiswa/i Fakultas Ilmu SosialDan Humaniora Program Study Manajemen dan Ilmu Pemerintahan Universitas Halmahera sebanyak 100 orang.

\section{Uji AsumsiKlasik}

\section{Uji Normalitas}


Uji normalitas bertujuan untuk menguji apakah dalam sebuah model regresi, variabel terikat, variabel bebas atau keduanya mempunyai distribusi normal atau tidak. Suatu data berdistribusi normal dilihat dari penyebarannya pada sumbu diagonal dari grafik dengan dasar keputusan sebagai berikut (Ghozali, 2012): a. Jika data menyebar disekitar garis diagonal dan mengikuti arah garis diagonal, maka model regresi memenuhi normalitas. $b$. Jika data menyebar jauh dari garis diagonal dan tidak mengikuti arah garis diagonal, maka model regresi tidak memenuhi normalitas. Berikut hasil uji normalitas disampaikandalam pada gambar dibawah ini.

\section{Gambar 4.2.1}

\section{Hasil Uji Normalitas}

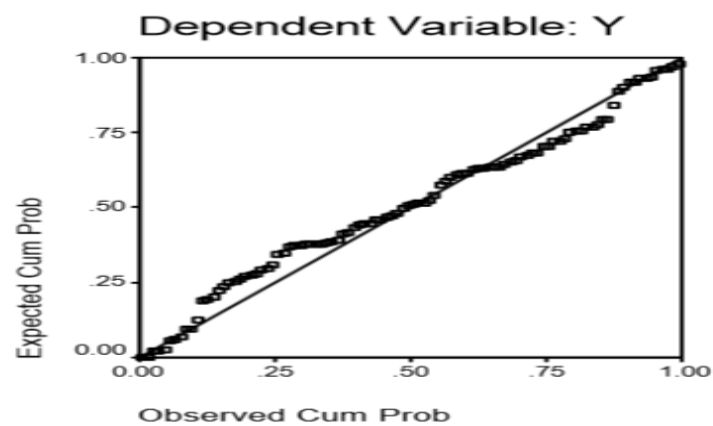

Berdasar Gambar 4.2.1 diatas, diketahui bahwa pada pengujian normalitas yang telah dilakukan memperlihatkan adanya titik yang mengikuti arah garis linier dari kiri bawah ke kanan atas sehingga variabel yang diuji mengindikasikan adanya gejala normalitas, dengan demikian variabel yang diuji sudah memenuhi uji asumsi normalitas yang disyaratkan.

\section{Hasil Uji Multikolinearitas}

Uji multikolonieritas bertujuan untuk menguji apakah model regresi ditemukan adanya korelasi antar variabel bebas (independen). dilihat dari nilai tolerance dan variance inflation factor (VIF). Tolerance mengukur variabel independen yang terpilih yang tidak dijelaskan oleh variabel independen lainnya. Jadi nilai tolerance yang rendah sama dengan nilai VIF tinggi (karena VIF $=1 /$ tolerance) nilai cut off yang umum di pakai untuk menunjukkan adanya multikolonieritas adalahnilai tolerance $>0,10$ atau sama dengan nilai VIF < 10 (Ghozali, 2012). Untuk lebih jelasnya dapat dilihat pada tabel dibawah ini:

\section{Gambar 4.2.2}

\section{Hasil Uji Multikolinearitas}




\begin{tabular}{|c|c|c|}
\hline \multirow{2}{*}{ Variabel } & \multicolumn{2}{|c|}{ Collinearity Statistics } \\
\cline { 2 - 3 } & Tolerance & VIF \\
\hline Tangibles $\left(\mathrm{X}_{1}\right)$ & 0,803 & 1,245 \\
\hline Reliability $\left(\mathrm{X}_{2}\right)$ & 0,858 & 1,165 \\
\hline Responsiveness $\left(\mathrm{X}_{3}\right)$ & 0,610 & 1,639 \\
\hline Assurance $\left(\mathrm{X}_{4}\right)$ & 0,742 & 1,348 \\
\hline Emphaty $\left(\mathrm{X}_{5}\right)$ & 0,713 & 1,402 \\
\hline Kepercayaan $(\mathrm{Z})$ & 0,551 & 1,815 \\
\hline
\end{tabular}

Keterangan : data primer diolah

Berdasar Gambar 4.2.2 diatas, diketahui bahwa pada pengujian multikolonieritas yang telah dilakukan memperlihatkan semua angka tolerance masih dibawah angka VIF,sehingga dapat disimpulkan bahwa tidak ada multikolonieritas antara variabel independen.

\section{Uji Heteroskedastisitas}

Uji heteroskedastisitas bertujuan untuk menguji apakah dalam model regresi terjadi ketidaksamaan varian dari residual suatu pengamatan ke pengamatan yang lain, maka disebut homoskedastisitas dan jika varian berbeda disebut heteroskedastisitas. Model regresi yang baik adalah yang homokedastisitas atau tidak terjadi heteroskedastisitas (Ghozali, 2009). Cara untuk mendeteksi ada atau tidaknya heterokedastisitas yaitu dengan melihat grafik plot (scatterplot) antara nilai prediksi variabel terikat (dependen/ZPRED) dengan residualnya SRESID.

Dasar analisis untuk scatterplot yaitu jika ada pola tertentu seperti titik yang ada membentuk pola tertentu yang teratur (bergelombang, melebar kemudian me- nyempit), maka kemudian mengindikasikan terjadinya heteroskedastisitas. Sebaliknya jika tidak ada pola yang jelas, serta titik menyebar di atas dan di bawah angka 0 (nol) pada sumbu Y, maka tidak terjadi heteroskedastisitas (Ghozali, 2009). Untuk lebih jelasnya hasil uji heteroskedastisitas dengan grafik plot (scatterplot) dapat dilihat pada dibawah ini:

Gambar 4.2.3

\section{Hasil Uji Heteroskedastisitas}

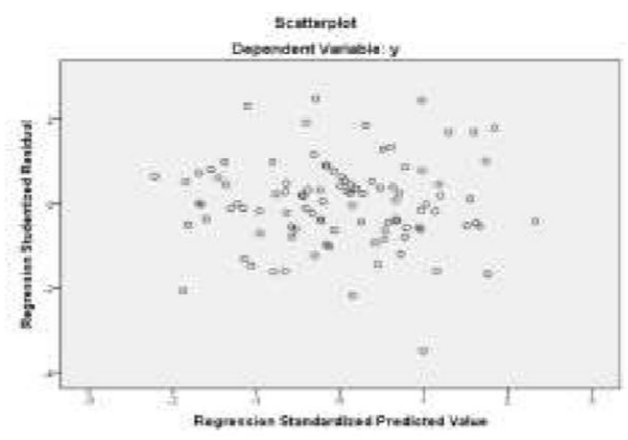

\section{Uji Autokorelasi}

Pengujian autokorelasi dimaksudkan untuk mengetahui apakah terjadi korelasi antara anggota serangkaian observasi yang diurutkan menurut waktu (time series) atau secara ruang (cross sectional). Hal ini mempunyai arti bahwa hasil suatu tahun tertentu dipengaruhi tahun 
sebelumnya atau tahun berikutnya. Terdapat korelasi atas data cross section apabila data di suatu tempat dipengaruhi atau mempengaruhi di tempat lain. Untuk mendeteksi ada atau tidaknya autokorelasi ini dapat dilakukan dengan menggunakan uji statistik Durbin - Watson. Adapun dasar pengambilan keputusan dalam uji Durbin - Watson ini dilakukan dengan mengadopsi argumen Singgih (2000),

sebagai berikut:

- Bila angka Durbin - Watson berada di bawah -2, berarti ada autokorelasi.

- Bila angka Durbin - Watson diantara -2 sampai +2, berarti tidak ada autokorelasi.

- Bila angka Durbin - Watson di atas +2 , berarti ada autokorelasi negatif.

Gambar 4.2.4

Hasil Uji Autokorelasi

\begin{tabular}{|l|c|}
\hline Variabel & Durbin-Watson \\
\hline Tangibles $\left(\mathrm{X}_{1}\right)$ & \\
Reliability $\left(\mathrm{X}_{2}\right)$ & \\
Responsiveness $\left(\mathrm{X}_{3}\right)$ & 1,855 \\
Assurance $\left(\mathrm{X}_{4}\right)$ & \\
Emphaty $\left(\mathrm{X}_{5}\right)$ & \\
Kepercayaan $(\mathrm{Z})$ & \\
\hline
\end{tabular}

Berdasarkan hasil uji autokorelasi dalam tabel di atas, selanjutnya diketahui bahwa nilai statistik Durbin Watson hasil perhitungan diatas sebesar 1,855, dimana nilai ini berada diantara -2 sampai +2 , dengan demikian, dari hasil penelitian ini menunjukkan tidak terjadi adanya gejala autokorelasi.

\section{Analisis Data}

Analisa Jalur Berdasarkan hasil pengujian anatara kualitas pelayanan akademik terhadap kepuasan mahasiswa

Tabel 4.3.1.

Persamaan Regresi Pengaruh Kualitas Pelayanan Terhadap Kepuasan Mahasiswa

\begin{tabular}{|l|l|l|l|l|l|}
\hline \multirow{2}{*}{ Model } & \multicolumn{2}{|l|}{\begin{tabular}{l}
\multicolumn{2}{|l|}{ Unstandardized } \\
Coefficients
\end{tabular}} & $\begin{array}{l}\text { Standardized } \\
\text { Coefficients }\end{array}$ & & \\
\cline { 2 - 5 } & B & Std. Error & Beta & T & Sig. \\
\hline Constant) & 5.489 & 1.763 & & 1.314 & .005 \\
Kualitas Pelayanan Akademik & .646 & .102 & .786 & 12.275 & .000 \\
\hline
\end{tabular}

Dari tabel 4.3.1. diatas dapat disimpulkan bahwa nilai koefisien regresi pada variabel kinerja layanan terhadap kepuasan mahasiswa yaitu positif dengan nilai sebesar 0,786 dan nilai signifikansinya sebesar $0,000<0,05$ sehingga mempunyai arti bahwa kualitas pelayanan 
akademik meningkat, maka akan meningkatkan kepuasan mahasiswa dengan asumsi variabel lain adalah tetap.

Analisa Jalur Berdasarkan hasil pengujian antara kualitas pelayanan akademik terhadap kepuasan mahasiswa

Tabel 4.3.2.

Persamaan Regresi Pengaruh Kualitas Pelayanan akademik

Terhadap Loyalitas Mahasiswa

Berikut tabelhasil uji regresi pengaruh kualitas pelayanan terhadap loyalitas mahasiswa

\begin{tabular}{|c|c|c|c|c|}
\hline Variabel & $\begin{array}{c}\text { Standardized } \\
\text { coeficients (beta) }\end{array}$ & $t_{\text {thitung }}$ & Probabilitas & Keterangan \\
\hline $\begin{array}{l}\text { Kualitas } \\
\text { Pelayanan }\end{array}$ & 0,723 & 14,978 & 0,000 & Signifikan \\
\hline $\mathrm{R}$ & 0,723 & & & \\
\hline$R$ square & 0,523 & & & \\
\hline
\end{tabular}

Dari tabel 4.3.2. diatas dapat disimpulkan bahwa nilai koefisien regresi pada variabel kinerja layanan terhadap loyalitas mahasiswa yaitu positif dengan nilai sebesar 0,000 dan nilai signifikansinya sebesar $0,000<0,05$ sehingga mempunyai arti bahwa kualitas pelayanan akademik berpengaruh positif signifikan terhadap loyalitas mahasiswa.

Analisa Jalur Berdasarkan hasil pengujian anatara kualitas pelayanan akademik terhadap kepuasan mahasiswa

Tabel 4.3.3.

Persamaan Regresi Pengaruh Kualitas Pelayanan akademik dan Kepuasan Mahasiswa Terhadap Loyalitas Mahasiswa

\begin{tabular}{|c|c|c|c|c|c|}
\hline & & oefficients ${ }^{a}$ & & & \\
\hline \multirow[b]{2}{*}{ Model } & \multicolumn{2}{|c|}{$\begin{array}{l}\text { Unstandardized } \\
\text { Coefficients }\end{array}$} & \multirow{2}{*}{\begin{tabular}{|l|}
$\begin{array}{l}\text { Standardized } \\
\text { Coefficients }\end{array}$ \\
Beta
\end{tabular}} & \multirow[b]{2}{*}{$\mathrm{T}$} & \multirow[b]{2}{*}{ Sig. } \\
\hline & B & Std. Error & & & \\
\hline (Constant) & 4.389 & 2.163 & & 2.414 & .008 \\
\hline Kualitas Pelayanan Akademik & .368 & .177 & .247 & 3.754 & .020 \\
\hline Kepuasan Mahasiswa & .546 & .252 & .586 & 4.275 & .000 \\
\hline
\end{tabular}

Dari persamaan regresi linier berganda tersebut di atas menunjukkan bahwa : a. Hasil persamaan regresi antara Kualitas Pelayanan Akademik terhadap loyalitas mahasiswa menunjukkan bahwa nilai koefisien regresi mempunyai parameter positif dan signifikan dengan nilai sebesar 0,247, dapat diartikan bahwa jika Kualitas Pelayanan Akademik meningkat, maka akan meningkatkan loyalitas mahasiswa dengan asumsi variabel lain adalah 
konstan. Nilai koefisien regresi antara kepuasan mahasiswa terhadap loyalitas mahasiswa menunjukkan parameter positif dan signifikan dengan nilai sebesar 0,586, mempunyai arti bahwa kepuasan mahasiswa meningkat, maka akan meningkatkan loyalitas mahasiswa dengan asumsi variabel lain adalah konstan.

\section{Pengujian Hipotesis}

Pengaruh Kualitas Pelayanan Akademik Terhadap Kepuasan Mahasiswa Pengujian hipotesis 1 ini digunakan untuk mengetahui ada tidaknya pengaruh antara kualitas pelayanan akademik terhadap kepuasan mahasiswa. Berdasarkan hasil output, diperoleh nilai t hitung untuk variabel kualitas pelayanan akademik sebesar 12,275 dengan nilai signifikansi sebesar 0,000 $<0,05$, sehingga nilai $\mathrm{t}$ hitung $=12,275>$ nilai $\mathrm{t}$ tabel $=2,0032$. Penjelasan tersebut dapat diartikan bahwa terdapat pengaruh yang signifikan antara kualitas pelayanan akademik terhadap kepuasan mahasiswa, dapat diartikan bahwa jika kualitas pelayanan akademik yang dilakukan Universitas Halmahera kepada para mahasiswa lebih ditingkatkan, maka akan meningkatkan kepuasan mahasiswa. Hal ini sejalan penelitian Indra Ade (2011) berdasarkan pada hasil pengujian data diperoleh kesimpulan bahwa Kualitas pendidikan dan Pelayanan pendidikan berpengaruh positif terhadap tingkat kepuasan mahasiswa Magister Manajemen Universitas mercu Buana secara uji parsial(uji t) maupun uji bersama(uji f). Dalam hal ini kualitas pelayanan akademik lebih bisa menjawab permasalahan yang muncul dalam menentukan kualitas jasa yang diberikan organisasi pendidikan tersebut, karena bagaimanapun para mahasiswa hanya akan bisa menilai kualitas yang mereka terima. Berdasarkan hasil pengujian dapat disimpulkan bahwa pengujian tersebut mampu menerima H1, sehingga dugaan kualitas pelayanan akademik berpengaruh terhadap kepuasan mahasiswa terbukti atau dapat diterima.

Pengaruh Kualitas Pelayanan Akademik Terhadap Loyalitas Mahasiswa.

Berdasarkan hasil pengujian antara kualitas pelayanan akademik terhadap loyalitas mahasiswa diperoleh nilai t hitung sebesar 3,754 nilai signifikansinya sebesar 0,020<0,05. sehingga nilai t hitung $=3,754>$ nilai t tabel $=2,0040$. Penjelasan tersebut dapat diartikan bahwa kualitas pelayanan akademikn berpengaruh terhadap loyalitas mahasiswa, memberikan pengertian bahwa semakin tinggi kualitas pelayanan akademik yang diberikan kepada para mahasiswa, maka akan semakin meningkatkan loyalitas para mahasiswa dalam menggunakan pendidikan pada Program Manajemen dan Ilmu Pemerintahan Universitas Halmahera. Hal ini sesuai dengan penelitian I Nyoman Rinala, I Made Yudana, dan Nyoman Natajaya (2013) memaparkan bahwa Kualitas pelayanan akademik dapat dijelaskan oleh faktor bukti fisik, keandalan, daya tanggap, empati yang memberikan efek kuat dan jaminan memberikan efek lemah. Kualitas pelayanan akademik berpengaruh signifikan terhadap 
loyalitas mahasiswa melalui kepuasan mahasiswa, sedangkan kualitas pelayanan akademik secara langsung berpengaruh tidak signifikan terhadap loyalitas

Mahasiswa pada STP Nusa Dua Bali. Dengan demikian kualitas pelayanan akademik yang diberikan akan lebih meningkatkan kualitas jasa/pelayanan karena pengukuran terhadap kualitas pelayanan telah membentuk tingginya loyalitas mahasiswa, dimana harapan mahasiswa terhadap kualitas jasa yang diberikan mengacu kepada harapan yang diinginkan mahasiswa. Berdasarkan hasil pengujian dapat disimpulkan bahwa pengujian tersebut mampu menerima $\mathrm{H} 2$, sehingga dugaan kualitas pelayanan akademik berpengaruh terhadap loyalitas mahasiswa dan terbukti atau dapat diterima.

Pengaruh Kualitas Pelayanan dan Kepuasan terhadap Loyalitas

Berdasarkan tabel 4.3.3. dapat diketahui pengaruh yang signifikan antara variabel kualitas pelayanan dan kepuasan terhadap loyalitas. Berdasarkan hasil uji koefiesien path pada tabel di atas didapatkan nilai probabilitas $\mathrm{F}$ hitung sebesar $0,000(\mathrm{p}<0,05)$, sehingga Ho ditolak, karena Ho ditolak maka variabel kualitas pelayanan dan kepuasan secara bersamasama (simultan) berpengaruh signifikan terhadap loyalitas. Besarnya sumbangan (kontribusi) variabel kualitas pelayanan dan kepuasan terhadap loyalitas dapat dilihat dari nilai Adjusted Rsquare yaitu sebesar 0,625. Ini artinya bahwa62,5\% variabel loyalitas dipengaruhi oleh variabel kualitas pelayanan dan kepuasan, sedangkan sisanya 37,5\% dipengaruhi oleh variabel-variabel yang lain yang tidak dibahas dalam penelitian ini.

\section{KESIMPULAN DAN SARAN}

\section{Kesimpulan}

Berdasarkan penelitian yang telah dilakukan maka dapat diperoleh kesimpulan sebagai berikut :

1. Terdapat pengaruh yang positif signifikan antara kualitas pelayanan akademik terhadap kepuasan mahasiswa, dapat diartikan bahwa jika kualitas pelayanan akademik yang dilakukan Universitas Halmaherakepada para mahasiswa lebih ditingkatkan, maka akan meningkatkan kepuasan mahasiswa.

2. Kualitas Pelayana Akademik berpengaruh positif signifikan terhadap loyalitas mahasiswa, memberikan pengertian bahwa semakin tinggi kualitas pelayanan akademik yang diberikan kepada para mahasiswa, maka akan semakin meningkatkan loyalitas para mahasiswa dalam menggunakan jasa pendidikan di Universitas Halmahera.

3. Terdapat pengaruh yang signifikan antara Kualitas layanan dan kepuasan mahasiswa terhadap loyalitas mahasiswa, dapat diartikan bahwa jika tingkat kepuasan mahasiswa 
meningkat karena pelayanan yang diberikan baik/meningkat, maka loyalitas mahasiswa juga akan meningkat.

\section{Saran}

Atas dasar kesimpulan yang telah dikemukakan di atas, maka saran dan harapkan yang berguna bagi kemajuan Universitas Halmahera adalah, fasilitas jasapendidikan serta kualitas pelayanan perlu ditingkatkan. Hal ini menjadi prioritas, agarMahasiswa dan juga calon pengguna jasa pendidikan di Universitas Halmahera tetap loyal terhadap Universitas Halmahera. Dengan demikian, pihak manajemen harus melakukan evaluasi dengan terus meningkatkan mutu jasa fasilitas pendidikan. Apalagi persaingan jasa pendidikan begitu kompetitif, maka mahasiswa akan puas dan loyal jika organisasi pendidikan mampu meningkatkan kualitas atau mutu jasa pendidikan.

\section{DAFTAR PUSTAKA}

Kotler, Philip Dan Kevin Lane Keller. 2007. Manajemen Pemasaran. Edisi Kedua Belas. Indeks : Jakarta

Umar, Husein. 1997. Study Kelayakan Bisnis. Edisi Ketiga. Gramedia Pustaka Utama : Jakarta Tjiptono, Fandy dan Anastasia Diana. 2003. Total Quality Manajemen. Edisi Revisi. Andy: Yogyakarta

Lupiyoadi, Rambat. 2001. Manajemen Pemasaran Jasa. Edisi Pertama. Salemba Empat: Jakarta

Ratminto dan Atik Winarsih. 2005. Manajemen Pelayanan. Pustaka Pelajar: Yogyakarta

Supranto. 2006. Pengukuran Tingkat Kepuasan Pelanggan. Cetakan Ketiga. Rineka Cipta: Jakarta

Aryani, Dwi dan Febrina Rosinta. (2010). Pengaruh Kualitas Layanan Terhadap Kepuasan Pelanggan dalam Membentuk Loyalitas Pelanggan. Jurnal Ilmu Administrasi danOrganisasi. Vol. 17 No. 2. ISSN: 0854-3844.

Yahya. (2013). Analisis Kualitas Layanan Jasa Pendidikan Terhadap Kepuasan Mahasiswa Pada Politeknik Negeri Sriwijaya. Jurnal Orasi Bisnis Edisi ke-X. ISSN: 2085-1375.

Indah Dwi, P. 2009. Analisis Pengaruh Pembelajaran dan Kualitas Pelayanan TerhadapKepuasan Mahasiswa dan Loyalitas Mahasiswa (Studi Kasus Pada Undaris Ungaran).Tesis Program Magister Manajemen, Universitas Diponegoro 
